\title{
RELATIONSHIP BETWEEN ECONOMIC GROWTH, FINANCIAL DEVELOPMENT AND WORKER'S REMITTANCES IN SOUTH ASIA ${ }^{1}$
}

\author{
Mobeen ur Rehman ${ }^{2}$ \\ Ph.D in Finance (SZABIST, Islamabad, Pakistan) \\ Assistant Professor at SZABIST \\ mobeenrehman@live.com \\ https://orcid.org/0000-0002-8889-9051 \\ Syed Jawad Hussain Shahzad \\ Ph.D in Finance (Universiti Malaysia Terengganu) \\ Associate Professor at Montpellier Business School \\ j.syed@montpellier-bs.com \\ https://orcid.org/0000-0003-3511-6057 \\ Memoona Kanwal \\ MSc. in Finance (COMSATS) \\ memoona.kanwal21@yahoo.com \\ https://orcid.org/0000-0002-7286-5404 \\ Sajid Ali \\ Ph.D in Finance (Universiti Malaysia Terengganu) \\ sajid.mahr@gmail.com \\ https://orcid.org/0000-0002-0784-2476
}

\begin{abstract}
Objective: this research aims to examine the relationship between financial development, remittances inflow and economic growth for South Asian countries. This study also aims to explore how the financial development of selected Asian countries is influenced by worker's remittances in short and long run periods.

Methodology: we construct index of financial development using eight indicators of banking, insurance and stock markets. We use panel data for all the countries of South Asian region from 19882013.

Results: our findings highlight that remittances inflows and economic growth have a positive and significant impact on financial development in long run. We also find evidence of bi-directional causality between inflows of foreign remittances and financial sector development.

\footnotetext{
${ }^{1}$ Paper received on: 05/06/2017. Desk reviewed on: 05/08/2017. $2^{\text {nd }}$ version recommended for publication in: 09/21/2017 by Luiz Felipe de Araújo Pontes Girão (Editor in chief). Published: 10/12/2017. Organization responsible for the periodical: UFPB.

${ }^{2}$ Address: Shaheed Zulfikar Ali Bhutto Institute of Science and Technology Street No \# 9 Plot \# 67 Sector \# H - 8/4, Islamabad (Adjacent to Bait-ul-Mal Office/F. G. Commerce College for Men).

DOI: http://dx.doi.org/10.18405/recfin20180108
} 
Contribution: this study attempts in contributing towards existing literature while determining the role of worker's remittances and economic growth on the financial development of South Asian countries.

Keywords: South Asian countries. Remittance inflows. Financial development index. Economic growth.

\section{INTRODUCTION}

In the past decade developing countries experienced an increasing role of inward remittances in international capital inflows. The level of inward remittance in the recipient countries increased more than the export revenues, international aid and Foreign Direct Investment (FDI). This makes it the second largest foreign exchange source both in terms of percentage of Gross Domestic Product (GDP) and in absolute terms. There are few evidence of countries in which the inward remittances account for only as much as 10 percent of their GDP. These countries among others include small pacific islands and Caribbean regions including Albania, Philippines and El Salvador. Given the magnitude of remittance inflows, the relationship between the level of growth and inward remittances has not received much attention in current literature. According to Docquier and Rapoport (2005), lack of cross country evidence is one of the major constraints in making analysis of the impact of remittance level on growth of the recipient country.

For developing countries, the transferred remittances of international migrants into their home countries represent major financial inflows source. These inflows sometimes exceed the traditional inflows like private capital inflows and official development assistance (Ali et al. 2014). As a result, the effect on economic activities from worker's remittances has received important considerations not only from policy makers but also for international research community. According to Kumar (2013) worker's remittances have significant positive impact on the economic growth, however, some other studies document a deteriorating impact of inward remittances on economic growth suggesting their compensatory nature (Chami et al, 2005). The inflows of foreign remittances in the developing countries have an estimated amount of $\$ 404$ with an annual growth of 3.5 percent in 2013 as per World Bank reports. It is also believed that large amount of inward remittances in the recipient countries follow unrecorded and unofficial channels and these can contribute up to more than 54 percent of the recorded inward remittances.

Inward remittances are a form of private inflows where part of their amount is spent on the investment and consumption. However, there is ample literature suggesting that such level of inward remittance contribute more towards the consumption purposes like land and housing as compared to the investments of productive nature. There is a priori ambiguity among the relationship of remittances, growth and financial development. For well-functioning financial markets, sustainable growth can be achieved by lowering transaction costs and thereby projecting the highest return yields. However, bad financial systems can be compensated by remittance inflows. This can be achieved by relaxing the liquidity constraints and allowing the entrepreneurs to use such remittances where funding from financial systems is difficult due to high lending costs or collateral reasons. According to past literature, excess to credit is one of the biggest concerns in developing economies due to stringent credit requirements.

Although few studies address the relationship among financial development, economic growth and remittances inflows, but either worker's remittances and/or economic development truly represents the financial development of any country is an open question. This issue, therefore merits careful investigation especially for the region where workers' remittances volume is quite substantial and can have important implications for the development policy. We hypothesize that both inward remittances and financial development have substantial explanation for the financial development of South Asian developing countries. 
Our study attempts in contributing towards existing literature while determining the role of worker's remittances and economic growth on the financial development of South Asian countries. We contribute to the debate on relationship of remittances and economic development with financial development in two ways. One, past studies used banking sector as the major financial development indicator. In this paper, we have used eight indicators of banking, insurance and stock markets from countries of the South Asia i.e. Afghanistan, Bangladesh, Bhutan, India, Maldives, Nepal, Pakistan, Sri Lanka and over a period 1988 to 2013. Second, we analyzed the interacting relationship among all the included variables i.e. remittances, economic development and financial development for developing countries of Asia. In particular, this study also aims to explore how the financial development of South Asian countries is influenced by worker's remittances in short and long run periods. Current literature on the impact of remittances on growth is qualitative and suggests that remittances are mostly spent on consumption whereas in our study we quantify the impact of worker's remittances and economic growth on financial development of South Asian countries.

Section 2 presents the past literature on our included variables and their underlying relationship followed by the methodology and conclusion in the subsequent sections.

\section{LITERATURE REVIEW}

In emerging economies, remittances inflows are the main source of external financing along with foreign direct investments. According to Yang (2008), remittance inflows in comparison to private capital have remained steady and rises during the periods of economic recessions and natural disasters. Levine and Schmukler (2007) reported that the level of remittance inflows (in absolute terms and in terms of gross domestic product percentage) has doubled than the level of foreign development assistance. Rajan and Subramanian (2005) concluded that remittance inflows unlike the foreign aid do not corrode the competitiveness of the recipient country. According to Javid et al. (2012), there is a significant positive impact of worker's remittances on economic growth. For countries with weak financial systems, increase in inward flow of remittances can serve as an alternative way of investment to increase the economic growth (Giuliano and Arranz 2009). Besides economic growth and improvements in financial system, remittances inflows can also address the issues of liquidity in the recipient country.

According to Terry and Wilson (2005) and Hinojosa (2003), the development impact through remittances inflows can be enhanced by an efficient role of remittance recipient bank. Giuliano and Arranz (2009) reported many indirect implications for recipient countries. These include investments in insurance companies for safer prospects of their associated dependents, availability of credit for financiers to make investments in equity markets as this can transmit liquidity in the markets of less developed countries. According to Orozco (2007), remittance inflows to the recipient country can also help in accessing their financial products and services that would be very difficult otherwise.

Aggarwal and Peria (2006) use data of eight countries from 1870-1913 and suggested a more than proportional effect of remittances on financial services. The impact of increasing level of remittance inflows in the Sub-Saharan African region is studied by Gupta et al. (2009). Although this region receives more financial aids as compared to the remittance inflows, these inflows impact financial sector development more positively than other developed countries. According to Giuliano and Arranz (2009) during his analysis of 100 developing countries, remittance inflows have much prominent effect in less developed countries as compared to the developed ones. Remittance inflows provide liquidity and act as an alternative investment source. Therefore, in the presence of proper remittance transfer channels, remittance inflows can lead towards the development in financial sector of the recipient country. Fayissa et al. (2010) concluded that the amount of incoming remittances in African countries can be effectively invested in traditional sources i.e. physical and human capital 
to attain economic stability. To investigate the linkage between remittance inflows and levels of cumulative deposits, and the relation between remittance inflows and aggregate credit issued by banking sector. Aggerwal et al. (2011) conducted their study by collecting data of 99 developing countries from 1975 to 2003 . They found positive relationship between financial sector development and inflows of remittances. It is also believed that remittances are mostly used for the consumption purpose rather than having a positive impact on financial development. Fayissa et al. (2012) concluded that incoming remittances have a positive effect on the financial development. They recognized that determinants of inward remittances also depend on the regions. Oke et al. (2011) in his study tested the relationship between financial sector development and remittance inflows on $\mathrm{Ni}$ geria from 1977 to 2009. To measure financial development, ratio of money supply to GDP, and private credit to GDP were used as indicators. Results highlighted that inflows of remittances in Nigeria had positive impact on financial development. The inward remittances should be supported through formulation and implementation of suitable policy as these are important for both internal and external sectors of the economy. Impact of remittance inflows on financial development in Bangladesh was examined by Chowdhury (2011). The results showed that remittance inflows are not dependent on the financial sector development of the recipient country.

Past studies have mixed results on the question that remittance inflows trigger recipient country's development in financial sector or not. Therefore, as proposed by Aggarwal et al. (2011), there is a need to further investigate the relationship between level of foreign remittance and financial development. We aim to identify the underlying relationship among financial development, remittances inflows and economic growth in South Asian countries. We selected South Asian countries because of large number of individuals working in developed countries. These countries receive large amount of foreign remittances that contribute towards these countries development and spending. Presented below is the methodology to find the underlying short and long term relationship among financial development, remittances inflows and economic growth.

\section{RESEARCH METHODOLOGY}

We initially investigate unit root properties of our variables followed by the short and long run co-integration test mainly including fully modified OLS, dynamic OLS and pooled mean group framework. Rational of applying these tests to our proposed model is explained the sections appended below.

\subsection{Stationarity properties of the variables}

First generation tests of unit root i.e. IPS assume that panel units are cross-sectional independent, except time effect. The second-generation unit root tests of panel data e.g. Pesaran (2007) relax this assumption and allows cross-sectional dependency. The literature highlights that externalities, unobserved common factors, residual interdependences and macroeconomic linkages in regions may result in cross-sectional dependence among the panel units. The cross-sectional dependence is examined by applying a simple test of Pesaran (2004) that estimates an average pair-wise correlation by obtaining the OLS residuals through individual Augmented Dickey-Fuller (ADF) regressions. The null hypothesis of cross-sectional independence is tested against the alternative of dependence. The test statistics show a value of 1.826 thus rejecting the null hypothesis and indicating the presence of cross-sectional dependence among South Asian countries that may have resulted due to increased economic and financial integration in the region. When these dependencies exist, IPS results may provide biased results. For this reason, we use Cross-Sectionally Augmented IPS (CIPS) test proposed by Pesaran (2007), as a second-generation test. Cross-Sectional Augmented Dickey-Fuller (CADF) regression is used by Pesaran (2007) for the panel unit root test and is presented below: 


$$
\Delta y_{i t}=\alpha_{i}+\rho_{i} y_{i, t-1}+c_{i} \bar{y}_{i, t-1}+\sum_{j=0}^{k} d_{t-j} \Delta \bar{y}_{t-j}+\varepsilon_{i, t}+\sum_{j=1}^{k} \delta_{i j} \Delta y_{i, t-j}+\varepsilon_{i, t},
$$

In the above equation, $\bar{y}_{i, t-1}=(1 / N) \sum_{i=1}^{N} y_{i, t-1}$ and $t_{i}(N, T)$ indicate the t-statistics of the estimate $\rho_{i}$ to compute individual ADF statistics. The CIPS statistics can then be calculated through following equation:

$$
C I P S=\left(\frac{1}{N}\right) \sum_{i=1}^{N} t_{i}(N, T)
$$

\subsection{Cointegration Analysis}

To handle the possible cross-country dependence, we apply Westerlund (2007) panel cointegration test. The common factor restriction suggests that both long-run parameters in their levels and short-run parameters in their first differences are equal. If the data does not conform to this restriction, then residual-based cointegration test losses its power. We use panel cointegration tests proposed by Westerlund (2007) as the former test avoids the common factor restriction and assume that the error-correction term is equal to zero in the conditional error-correction model. Hence, the rejection of no error-correction, can be inferred as cointegration exists between the variables under study. Data generation process according to error-correction tests is presented as below:

$$
\left.\Delta Y_{i t}=\delta_{i}^{\prime} d_{t}+\alpha_{i}\left(Y_{i t-1}-\beta_{i}^{\prime} X_{i t-1}\right)+\sum_{j=1}^{p_{i}} \alpha_{i j} \Delta Y_{i t-j}\right)+\sum_{j=0}^{p_{i}} \alpha_{i j} \Delta X_{i t-j}+\varepsilon_{i t},
$$

Where $d_{t}$ indicates the deterministic term, $Y_{i t}$ shows financial development and $X_{i t}$ indicates the set of independent variables. Eq. (7) can be rewritten as:

$$
\left.\Delta Y_{i t}=\delta_{i}^{\prime} d_{t}+\alpha_{i} Y_{i t-1}-\lambda_{i}^{\prime} X_{i t-1}+\sum_{j=1}^{p_{i}} \alpha_{i j} \Delta Y_{i t-j}\right)+\sum_{j=0}^{p_{i}} \alpha_{i j} \Delta X_{i t-j}+\varepsilon_{i t},
$$

In the above equation, $\lambda_{i}^{\prime}=-\alpha_{i} \beta_{i}^{\prime}$. The correction of $Y_{i t-1}-\beta_{i}^{\prime} X_{i t-1}$ system back to its equilibrium is determined through parameter $\alpha_{i}$ after a sudden shock. If $\alpha_{i}<0$, then the model is considered errorcorrecting and hence $Y_{i t}$ and $X_{i t}$ are cointegrated. If $\alpha_{i}=0$, we conclude that there is neither error correction nor cointegration. The null hypothesis for all countries of the panel is $\alpha_{i}=0$ whereas alternative hypothesis is $\alpha_{i} \neq 0$. The alternative hypothesis considers that $\alpha_{i}$ is different for different cross-sectional units.

\subsection{Long run relationship estimation}

After examining the presence of cointegrating relation among variables, it is important to estimate the long run coefficients. If cointegration is present in panel data, several techniques like OLS, Fully Modified OLS (FMOLS), Dynamic OLS (DOLS) and Pooled Mean Group (PMG) can be used to estimate the long- and short-run coefficients. Properties of several OLS techniques are analyzed by Chen et al. (1999) and they suggest that FMOLS and DOLS estimators provide promising results in comparison to OLS. Therefore, we use FMOLS and DOLS for long-run parameters whereas 
PMG for short-run estimation for explaining the linkage between economic growth, financial development and remittances.

The FMOLS estimator proposed by Pedroni $(1999 b ; 2001)$ is used for estimate the long-run coefficients. It has several advantages i.e. consistent estimates of $\beta$ parameters for small samples, control for possible endogeneity and serial correlation. An expression for FMOLS ${ }^{3}$ estimation is as follow:

$$
y_{i t}=y_{i, t-1}=e_{i t}
$$

The order of integration for the innovating vector is $\omega_{i t}=\left(\mu_{i t}, e_{i t}\right)^{\prime}$ is $\mathrm{I}(0)$ along with the asymptotic long-run covariance vector $\Omega_{i}=\left[\begin{array}{ll}\Omega_{11 \mathrm{i}} & \Omega_{12 i} \\ \Omega_{21 i} & \Omega_{22 i}\end{array}\right]$ and auto covariance $\Gamma_{i}$, and $x_{i t}=\left(y_{i t}, z_{i t}\right)$ is integrated of order 1 , given $y_{i t}$ and $z_{i t}$ are cointegrated.

The application of dynamic OLS estimator by adding lead/lag values of regressor with first difference add parametric errors adjustment. This parametric adjustment not only help to obtain an unbiased estimator for long-run parameters, but also rectifies the endogeneity issue. The following equation is used to obtain the dynamic OLS estimators.

$$
Y_{i t}=\alpha_{i}+X_{i t}^{\prime} \beta+\sum_{j=-q_{1}}^{j=q_{2}} C_{i j} \Delta X_{i t+j}+v_{i t}
$$

Where $\mathrm{X}=[\mathrm{R}, \mathrm{G}]$, and $C_{i j}$ provides the coefficients of lag or lead of first differenced explanatory variables. The DOLS estimation of coefficients is as follow:

$$
\hat{\beta}_{D O L S}=\sum_{i=1}^{N}\left(\sum_{t=1}^{T} z_{i t} z_{i t}^{\prime}\right)^{-1}\left(\sum_{t=1}^{T} z_{i j} \hat{y}_{i t}^{+}\right)
$$

Where $z_{i t}=\left[X_{i t}-\bar{X}_{i}, \Delta X_{i, t-q}, \ldots \ldots . \Delta X_{i, t+q}\right]$ is vector of regressors, and $\hat{y}_{i t}^{+}\left(\hat{y}_{i t}^{+}=y_{i t}-\bar{y}_{i}\right)$ is the GDPPC variable.

\subsection{Short run relationship and panel causality}

We apply Pooled Mean Group (PMG) methodology proposed by Pesaran et al. (1999). This approach helps to simultaneously estimate both short- and long-run coefficients in panel error-correction model (PECM). The PMG is considered as an intermediate estimator because of pooling and averaging techniques that allows the short-run dynamics to differ for individual countries. However, it forces long-run coefficients to remain the same. In doing so, a long-run equation is estimated and residuals are obtained. Then the lag values of these residuals are used as error correction terms in the following dynamic error correction model:

$$
\begin{aligned}
& \Delta F_{i t}=\beta_{1 j}+\sum_{k=1}^{p} \beta_{11 i k} \Delta F_{i t-k}+\sum_{k=1}^{p} \beta_{12 i k} \Delta R_{i t-k}+\sum_{k=1}^{p} \beta_{13 i k} \Delta G_{i t-k}+\lambda_{1 i} \varepsilon_{i t-1}+v_{1 i t} \\
& \Delta R_{i t}=\beta_{2 j}+\sum_{k=1}^{p} \beta_{21 i k} \Delta F_{i t-k}+\sum_{k=1}^{p} \beta_{22 i k} \Delta R_{i t-k}+\sum_{k=1}^{p} \beta_{23 i k} \Delta G_{i t-k}+\lambda_{2 i} \varepsilon_{i t-1}+v_{2 i t}
\end{aligned}
$$

\footnotetext{
${ }^{3}$ Panel FMOLS estimator for the $\beta$ is $=N^{-1} \sum_{i=1}^{n}\left(\sum_{t=1}^{T} y_{i t}-\hat{y}\right)^{-1}\left(\sum_{t=1}^{T} y_{i t}-\hat{y}\right) z_{i t}^{*}-T \hat{\eta}_{i}$. In this expression, $\hat{L}_{i}$ is the lower triangular decomposition of $\hat{\Omega}_{i}, z_{i t}^{\prime}=\left(z_{i t}-\bar{z}-\frac{L_{21 i}}{L_{22 i}} \Delta y_{i t}\right.$ and $\hat{\eta}_{i=\Gamma_{21 i}+\Omega_{21 i}^{0}} \frac{L_{21 i}}{L_{22 i}}\left(\Gamma_{22 i}+\Omega_{22 i}^{0}\right)$
} 


$$
\Delta G_{i t}=\beta_{3 j}+\sum_{k=1}^{p} \beta_{31 i k} \Delta F_{i t-k}+\sum_{k=1}^{p} \beta_{32 i k} \Delta R_{i t-k}+\sum_{k=1}^{p} \beta_{33 i k} \Delta G_{i t-k}+\lambda_{3 i} \varepsilon_{i t-1}+v_{3 i t}
$$

In the above equations, $\Delta$ indicates first-difference and $p$ shows optimal lag length. We consider two lags according to Akaike information criterion.

\section{DATA AND PRELIMINARY STATISTICS}

This study is conducted on the South Asian countries i.e. Afghanistan, Bangladesh, Bhutan, India, Maldives, Nepal, Pakistan, Sri Lanka. Data on Gross Domestic Product (proxy for economic growth, G), remittance inflows, $R$ (as a percentage of GDP) and financial development indicators ${ }^{4}, \mathrm{~F}$ is extracted from 1988 to 2013 from World Bank Development Indicators. Table 1 presents the descriptive statistics and correlation between the variables. Remittances inflows are $11.87 \%$ of GDP in South Asia, economic growth is at $6.98 \%$ and financial development index show a value of 1.32 percent value on average. Correlation of financial development with remittances and economic growth is positive and significant. However, remittances inflows are negatively correlated with economic growth. These dynamic associations are important for further examining the cause-and-effect relationship in details.

Table 1: Descriptive Statistics and Correlation

\begin{tabular}{|c|c|c|c|}
\hline & $\mathrm{F}$ & $\mathrm{R}$ & $\mathrm{G}$ \\
\hline Mean & 1.322 & 11.874 & 6.983 \\
\hline Maximum & 4.037 & 5.698 & 7.986 \\
\hline Minimum & -1.297 & 3.596 & 5.598 \\
\hline Std. Dev. & 2.328 & 0.596 & 4.266 \\
\hline Skewness & 1.230 & 0.297 & 1.995 \\
\hline Kurtosis & 4.315 & 2.295 & 6.954 \\
\hline Jarque-Bera & $38.11^{* * *}$ & $5.790^{*}$ & $159.4^{* * *}$ \\
\hline $\mathrm{F}$ & 1 & & \\
\hline $\mathrm{R}$ & $0.347^{* *}$ & 1 & \\
\hline G & $0.635^{* * *}$ & $-0.295^{* * *}$ & 1 \\
\hline
\end{tabular}

Note: ${ }^{* * *},{ }^{* *} \&^{*}$ show $1 \%, 5 \%$ and $10 \%$ level of significance, respectively. All variables are presented as per unit of GDP.

\section{ANALYSIS AND DISCUSSION}

We determine the stationarity of variables before deciding appropriate methodology for integration. Pesaran (2007) tabulated the critical values for various deterministic terms. Table 2 provide the results of CIPS tests in the presence of constant and a trend. The unit root null hypothesis cannot be rejected at level for all the three variables indicating that the variables are integrated at order one.

Table 2: CIPS Panel unit root test results

\begin{tabular}{lllll}
\hline Variables & \multicolumn{2}{c}{ Level } & \multicolumn{2}{c}{ First difference } \\
& Constant & Trend & Constant & Trend \\
\hline F & -0.895 & -1.347 & $-2.317^{* *}$ & $-2.812^{* *}$ \\
R & -1.396 & -2.781 & $-3.272^{*}$ & $-3.340^{*}$ \\
G & -1.576 & -1.392 & $-2.434^{*}$ & $-2.930^{* * *}$ \\
\hline
\end{tabular}

Note: ${ }^{* *},{ }^{* *} \& *$ show $1 \%, 5 \%$ and $10 \%$ level of significance, respectively.

\footnotetext{
${ }^{4}$ Financial development index is formulated using Principle Component Analysis (PCA) on banking, insurance and stock market indicators provided in Appendix A.
} 
There are four different statistics proposed by Westerlund (2007). In panel tests, i.e. $P_{t}$ and $P_{a}$, we consider an alternative hypothesis of cointegration among whole panel $\left(H_{1}: \alpha_{i}=\alpha<0\right.$ for all i), whereas an alternative hypothesis of group mean statistics $G_{t}$ and $G_{a}$ consider at least one crosssection unit cointegration $\left(H_{1}: \alpha_{i}<0\right.$ for at least one $\left.i\right)$. This test allows for heterogeneity in panel units and provides bootstrapped $\mathrm{p}-$. These values are robust against cross-sectional dependencies. Values for all four test statistics are shown in Table 3. In all four cases, the respective null hypothesis can be rejected at $10 \%$ level of significance. The results of bootstrapped p-values also provide strong evidence of cointegrating relationship between financial development, remittances and economic growth.

Table 3: Westerlund (2007) panel cointegration tests

\begin{tabular}{cccc}
\hline Statistic & Value & $p$-value & Robust $p$-value \\
\hline$G_{t}$ & -6.386 & 0.050 & 0.004 \\
$G_{a}$ & -4.942 & 0.042 & 0.001 \\
$P_{t}$ & -5.536 & 0.052 & 0.009 \\
$P_{a}$ & -7.437 & 0.052 & 0.010
\end{tabular}

Notes: Width of Bartlett-kernel window is set to 2. Optimal lag/lead length is determined by Akaike Information Criterion (AIC) with a maximum lag/lead length of 2. Bootstrapped pvalues robust against cross-sectional dependencies are obtained by setting the bootstrap value to 200 .

Table 4 present results of FMOLS for individual and panel data. The growth and remittance coefficients are positive and significant in seven out of eight countries. Economic growth has positive impact on financial development in Afghanistan, Bangladesh, Bhutan, India, Maldives, Nepal, Pakistan, however, remittances inflows positively impact financial development in Afghanistan, Bangladesh, Bhutan, Maldives, Nepal, Pakistan, Sri Lanka. Remittances have positive but insignificant impact on the financial development in India. The positive and negative coefficient values suggest that increase (decrease) in economic growth and remittances leads to increase (decrease) in financial development in South Asian countries. The results of FMOLS at group level show that all coefficients are statistically significant and positive. Results of FMOLS indicate that 1\% increase in economic growth increases the financial development by about $8.39 \%$ whereas $1 \%$ increase in remittances as a percentage of GDP leads to an increase in financial development by about $0.15 \%$ respectively for South Asian countries.

Table 4: FMOLS country-specific results (F: dependent variable)

\begin{tabular}{lccc}
\hline Country & $\mathrm{G}$ & $\mathrm{R}$ & Constant \\
\hline Pakistan & $4.878^{* *}$ & $0.318^{* * *}$ & $-5.637^{*}$ \\
India & $11.51^{* * *}$ & 0.155 & $-13.05^{* * *}$ \\
Sri Lanka & -1.362 & $0.717^{* *}$ & 8.284 \\
Bangladesh & $7.137^{* * *}$ & $0.201^{* * *}$ & $-7.285^{* * *}$ \\
Nepal & $9.507^{* * *}$ & $0.084^{* * *}$ & $-9.813^{* * *}$ \\
Afghanistan & $8.549^{* *}$ & $0.035^{*}$ & $9.897^{* * *}$ \\
Bhutan & $5.659^{* *}$ & $0.598^{*}$ & $5.659^{* * *}$ \\
Maldives & $6.332^{* * *}$ & $0.359^{* *}$ & $23.65^{* * *}$ \\
Panel & $8.397^{* * *}$ & $0.153^{* * *}$ & - \\
Note: ${ }^{* * *},{ }^{* *} \&$ show $1 \%, 5 \%$ and $10^{*} \%$ level of significance, respectively. &
\end{tabular}


Tables 5 shows the results of DOLS at individual as well as panel level. Both economic growth and remittances are positive and significant in most of the countries. Similarly, the panel results also highlight the positive impact of remittances and economic growth on the financial development in South Asia. Results of both FMOLS and DOLS are consistent and conclude a positive long run impact of economic growth and remittances on financial development of South Asian countries.

Table 5: DOLS country-specific results (FD: dependent variable)

\begin{tabular}{lccc}
\hline Country & $\mathrm{G}$ & $\mathrm{R}$ & Constant \\
\hline Pakistan & $7.133^{* * *}$ & $0.379^{* * *}$ & $-7.707^{* * *}$ \\
India & $13.72^{* * *}$ & 0.045 & $-15.41^{* * *}$ \\
Sri Lanka & -0.486 & 0.695 & 0.055 \\
Bangladesh & $7.561^{* * *}$ & $0.208^{* * *}$ & $-8.400^{* * *}$ \\
Nepal & $11.15^{* * *}$ & $0.072^{* *}$ & $-11.27^{* * *}$ \\
Afghanistan & $10.563^{* *}$ & $0.098^{*}$ & $7.635^{*}$ \\
Bhutan & $5.326^{*}$ & $0.136^{* *}$ & $6.329^{* * *}$ \\
Maldives & $6.236^{* * *}$ & $0.236^{*}$ & $2.326^{* * *}$ \\
Panel & $8.338^{* * *}$ & $0.098^{* *}$ & - \\
\hline
\end{tabular}

Note: ${ }^{* * *}{ }^{* *} \&{ }^{*}$ show $1 \%, 5 \%$ and $10 \%$ level of significance, respectively.

Short-run causality from remittance and growth to financial development in Eq. 8a is analyzed based on $H_{0} ; \beta_{12 i k}=0 \forall i k$, and $H_{0} ; \beta_{13 i k}=0 \forall i k$, respectively. In eq. (8a)-(8c), short-run causality is examined through the statistical significance of partial F-statistic of right-hand-side variables. Significance using a t-statistic on the coefficient $\lambda$ of error correction term, $\varepsilon_{i t-1}$ in eq. (8a)-(8c) is used to ascertain the presence (absence) of any long-run causality.

Table 6: Lag order selection

\begin{tabular}{ccccccc}
\hline Lag & LogL & LR & FPE & AIC & SC & HQ \\
\hline 0 & -504.561 & NA & 15.887 & 11.279 & 11.362 & 11.312 \\
1 & 115.350 & 1184.721 & 0.002 & -2.296 & $-1.963^{*}$ & -2.162 \\
2 & 133.193 & $32.909^{*}$ & $0.000^{*}$ & $-2.493^{*}$ & -1.909 & $-2.257^{*}$ \\
3 & 140.795 & 13.515 & 0.001 & -2.462 & -1.628 & -2.126 \\
\hline *
\end{tabular}

* indicates lag order selected by the criterion

Results of short and long run causality are reported in Table 7. The estimation of eq. 8 shows that lagged error-correction term coefficient is significant and negative with a lower value. Hence, speed of adjustment (i.e. 0.17) towards the long-run equilibrium is slow. Negative error correction term highlights the existence of the long run Granger causality running from economic growth and remittances to financial development. Similarly, in eq. $8 b-8 c$, co-efficient of error correction term is -0.006 and -0.422 , respectively. Results of eq. $8 \mathrm{c}$ indicate long-run relationship from economic growth and financial development to remittances inflows with a moderate speed towards long-run equilibrium. In the short-run, there is a bidirectional causality between financial development and remittances inflows in South Asia. No short run relationship exists between financial development and economic growth and between remittances inflows and economic growth. The PMG analysis support the earlier reported long-run relationship (see results of FMOLS and DOLS) and reveal the short-run dynamics of economic growth, financial development and remittances inflows in South Asia.

Table 7: PMG Panel Causality Test

\begin{tabular}{ccccc}
\hline & $\mathrm{F}$ & $\mathrm{G}$ & $\mathrm{R}$ & $\mathrm{ECT}$ \\
\hline $\mathrm{F}$ & - & -3.397 & $.0465^{* *}$ & $-0.170^{* * *}$ \\
$\mathrm{G}$ & -.003 & - & -.001 & $-0.006^{*}$ \\
$\mathrm{R}$ & $.189^{*}$ & -34.591 & - & $-0.422^{* * *}$ \\
\hline
\end{tabular}

Notes: ${ }^{* * *},{ }^{* *} \&{ }^{*}$ show $1 \%, 5 \%$ and $10 \%$ level of significance, respectively. 


\section{CONCLUSION}

This study explores the relationship between economic growth, financial development, and remittance inflows using data on South Asian countries over the period of 1988-2013. Previous studies utilized banking sector indicators as a measure of financial development with mixed results. We used eight different banking, insurance and stock markets indicators to formulate a financial development index. Stationarity of the variables is examined through CIPS panel unit root test. To examine cointegration between variables, we applied Westerlund (2007) panel cointegration approach. Long-run coefficients are estimated through FMOLS and DOLS techniques whereas PMG framework is applied to determine the direction of causality between variables in the South Asian countries.

Our results indicate that all variables are integrated at first order of stationarity. Both above mentioned cointegration approaches support the existence of long-run relationship between financial development, remittances inflows and economic growth. The FMOLS and DOLS results show that both economic growth and remittances inflows have a positive and significant impact on financial development in long run. The causality analysis also supports the existence of long run equilibrium relationship between the variables. In short run, remittances inflows cause financial development whereas feedback effect is also observed in the South Asian countries.

Economic growth and remittance inflows have important role in the financial development of our sample markets. This has important implications for emerging and developing Asian countries since our study is based on Afghanistan, Bangladesh, Bhutan, India, Maldives, Nepal, Pakistan, Sri Lanka. Workers from the developing countries working abroad contribute in economic growth through remittances in less financially developed countries as an alternative to finance investment. These remittances help in minimizing the credit constraints to boost economic growth and improve the capital allocation by acting as a substitute of inexistent or inefficient credit markets. Our findings suggest an investment channel in the form of inward remittances to cover the gap between performance of financial sector and the credit needs of the population of any developing economy. An increasing level of remittances can also help in overcoming liquidity constraints in the countries with less developed financial systems.

However, there can be many other channels other than the economic growth and inward remittances that can affect the financial development of an economy. Therefore, this presents the limitation as well as future implication of our study. Furthermore, future research can also benefit in exploring the potential moral hazards resulting from an increasing level of inward remittances thus presenting negative implication of remittances (see Giuliano et al., 2009). Our study therefore, provides the macro level evidence of how inward remittances and economic growth can help the financial development in developing Asian economies.

\section{REFERENCES}

Aggarwal, R., Demirgüç-Kunt, A., \& Pería, M. S. M. (2011). Do remittances promote financial development? Journal of Development Economics, 96(2), 255-264.

Aggarwal, R., Demirguç-Kunt, A., \& Pería, M. S. M. (2006). Do worker' Remittances Promote Financial Development? World Bank Policy Research Paper Series, WBPR WP No. 3975, The World Bank.

Ali, S., Hamid, W., Muhammad, A., Raheel Abbas, K., Muhammad, A., \& Mukhtyar, K. (2014). Foreign Capital and Investment in Pakistan: A Cointegration and Causality Analysis. University Library of Munich, Germany.

Beck, T., Demirguç-Kunt, A., \& Levine, R. (2007). Finance, inequality and the poor. Journal of economic growth, 12(1), 27-49. 
Breitung, J., (2000). The local power of some unit root tests for panel data. Advances in Econometrics, $15,161-177$.

Chami, R., Fullenkamp, C., \& Jahjah, S. (2005). Are Immigrant Remittance Flows a Source of Capital for Development? IMF Economic Review, 52(1), 55.

Chen, B., McCoskey, S., Kao, C., (1999). Estimation and inference of a cointegrated regression in panel data: a Monte Carlo study. American Journal of Mathematical and Management Sciences, $19,75-114$.

Chowdhury, M. B. (2011). Remittances flow and financial development in Bangladesh. Economic Modelling, 28(6), 2600-2608.

Docquier, F., \& Rapoport, H. (2012). Globalization, brain drain, and development. Journal of Economic Literature, 50(3), 681-730.

Fayissa, B., \& Nsiah, C. (2010). The Impact of Remittances on Economic Growth Development in Africa. American Economist, 55(2).

Fayissa, B., \& Nsiah, C. (2012).Financial Development and Remittances in Africa and the Americas: A Panel Unit-Root Tests and Panel Cointegration Analysis. Working Papers 201201, Middle Tennessee State University, Department of Economics and Finance.

Giuliano, P., \& Ruiz-Arranz, M. (2009). Remittances, financial development, and growth. Journal of Development Economics, 90(1), 144-152.

Gupta, S., Pattillo, C. A., \& Wagh, S. (2009). Effect of remittances on poverty and financial development in Sub-Saharan Africa. World Development, 37(1), 104-115.

Hinojosa Ojeda, Raul (2003). Transnational Migration, Remittances and Development in North America: Globalization Lessons from the Oaxa-California Transnational Village/Community Modeling Project. Presented at "Remittances as a Development Tool in Mexico" organized by the Multilateral Investment Fund (MIF) of the Inter-American Development Bank (IDB), Mexico City, Mexico, October 28, 2003.

Im, K.S., Lee, J., Tieslau, M., (2005). Panel LM unit-root tests with level shifts. Oxford Bulletin of Economics and Statistics, 67(3), 393-419.

Javid, M., Arif, U., \& Qayyum, A. (2012). Impact of remittances on economic growth and poverty. Academic Research International, 2.

Kumar, N. (2013). Financial inclusion and its determinants: evidence from India. Journal of Financial Economic Policy, 5(1), 4-19.

Levin, A., Lin, C.F., (1993). Unit Root Tests in Panel Data: New Results. Discussion paper. Department of Economics, UC-San Diego.

Levin, A., Lin, C.F., Chu, C., (2002). Unit root tests in panel data: asymptotic and finite sample properties. Journal of Econometrics, 108, 1-24.

Levine, R., \& Schmukler, S. L. (2007). Migration, spillovers, and trade diversion: The impact of internationalization on domestic stock market activity. Journal of Banking E Finance, 31(6), 1595-1612.

Oke, B. O., Uadiale, O. M., \& Okpala, O. P. (2011). Impact of Workers' Remittances on Financial Development in Nigeria. International Business Research, 4(4), 218-225.

Orozco, M. (2007). Worker Remittances and the Financial Sector: issues and lessons in the South Caucasus. The European Bank for Reconstruction and Development, Bendixen and Associates.

Paola Giuliano and Marta Ruiz-Arranz, (2009). Remittances, financial development, and growth. Journal of Development Economics, 90(1), 144-152.

Pedroni, P. (2001). Fully modified OLS for heterogeneous cointegrated panels. Advances in econometrics, $15,93-130$. 
Pedroni, P., (1999). Critical values for cointegration tests in heterogeneous panels with multiple regressors.Oxford Bulletin of Economics and Statistics, 61, 653-670.

Pedroni, P., (2004). Panel cointegration: asymptotic and finite sample properties of pooled time series tests with an application to the PPP hypothesis: new results. Econometric Theory, 20, 597-627.

Pesaran, M. H., (2004). General Diagnostic Tests for Cross Section Dependence in Panels.Cambridge Working Papers in Economics no. 435.University of Cambridge.

Pesaran, M. H., (2007). A simple panel unit root test in presence of cross section dependence. Journal of Applied Econometrics, 22, 265-312.

Pesaran, M. H., Shin, Y., \& Smith, R. P. (1999). Pooled mean group estimation of dynamic heterogeneous panels. Journal of the American Statistical Association, 94(446), 621-634.

Rajan, Raghuram, and Arvind Subramanian, (2005). What Undermines Aid's Impact on Growth? International Monetary Fund Working Paper 05/126.

Terry, Donald F. and Steven R Wilson, (2005). Beyond Small Change: Making Migrant Remittances Count. Washington, D.C.: Inter-American Development Bank

Westerlund, J., 2007. Testing for error correction in panel data.Oxford Bulletin of Economics and Statistics, 69(6), 709-748.

Yang, Dean, (2008). Coping with Disaster: The Impact of Hurricanes on International Financial Flows, 1970-2002.The B.E. Journal of Economic Analysis \& Policy, 8, 13.

\section{Appendix A}

\begin{tabular}{|l|l|l|}
\hline \multicolumn{2}{|l|}{ Financial development indicators } \\
\hline S. No. & \multicolumn{1}{|c|}{ Indicator } & \multicolumn{1}{|c|}{ Sector } \\
\hline 1. & Liquid liabilities as \% of GDP & Banking \\
\hline 2. & Deposit money bank assets as \% of GDP & Banking \\
\hline 3. & $\begin{array}{l}\text { Private credit by deposit money banks and other financial institutions as \% } \\
\text { of GDP }\end{array}$ & Banking \\
\hline 4. & Stock market capitalization as \% of GDP & Stock market \\
\hline 5. & Stock market total value traded ratio as \% of GDP & Stock market \\
\hline 6. & Stock market turnover as \% of GDP & Stock market \\
\hline 7. & Life insurance premium volume as \% of GDP & Insurance \\
\hline 8. & Non-life insurance premium volume as \% of GDP & Insurance \\
\hline
\end{tabular}

